\title{
Lower eyelid aspergillosis infection mimicking a pyogenic granuloma in a pregnant lady
}

\author{
Deepsekhar Das ำ, Sujeeth Modaboyina 지 , Agam Bhandari, Sahil Agrawal
}

Dr Rajendra Prasad Centre for Ophthalmic Sciences, AllMS, New Delhi, Delhi, India

\section{Correspondence to} Dr Sahil Agrawal; agrawalsahil03.acad@gmail. com

Accepted 19 November 2020

\section{DESCRIPTION}

Aspergillus is a transient contaminant of the ocular flora. ${ }^{1}$ It can cause a variety of infections in the eye, ranging from keratitis to endophthalmitis to orbital cellulitis. While invasive fungal infections are classically described in immunocompromised states, they have also been described in immunocompetent individuals.

Pregnancy is not an immunocompromised state; however, there is a high degree of immunomodulation occurring in the mother's body to save the fetus from rejection. These modulatory processes are highly selective in its areas, and most other systemic organs have a negligible spillover of this effect.

A 34-year-old pregnant woman presented with a pigmented mass in her left lower eyelid for the past 2 weeks (figure 1 ). The patient was at 7 months of gestational age.

On examination, she was alert, conscious with stable vitals. There was no evidence of any fever, pallor or icterus. On ocular examination, visual acuity in both eyes was $6 / 6$, with intraocular pressure of $12 \mathrm{~mm} \mathrm{Hg}$ and $14 \mathrm{~mm} \mathrm{Hg}$ in the right and the left eye, respectively. There was a large pigmented mass on the left lower eyelid measuring $16 \times 12 \mathrm{~mm}$, along with mechanical ectropion of the lower lid. On slit lamp examination, there was left palpebral conjunctival congestion adjacent to the mass. Rest of the anterior segment and posterior segment examination of both eyes were within normal limits.

Based on the appearance, a provisional diagnosis of left eye lower eyelid pyogenic granuloma was made and the patient was planned for excision biopsy of the lesion. The biopsy was performed, and the lesion was removed (figure 2). Histopathological examination of the lesion revealed septate hyphae suggestive of aspergillosis (figure 3 ). However, the removed mass was not sent for microbiological studies. At the 3-week follow-up, the patient did not have any evidence of recurrence (figure 4).

Aspergillus is a ubiquitous fungus found particularly in the soil and decaying vegetation. ${ }^{2}$ There

(c) BMJ Publishing Group Limited 2020. No commercial re-use. See rights and permissions. Published by BMJ.

\section{To cite: Das $D$,}

Modaboyina S, Bhandari A et al. BMJ Case Rep

2020;13:e238732

doi:10.1136/bcr-2020-

238732

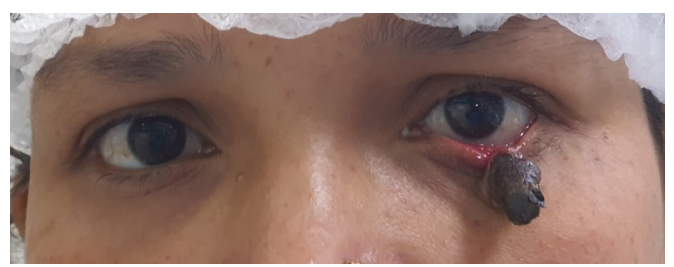

Figure 1 Clinical picture of the patient at presentation.

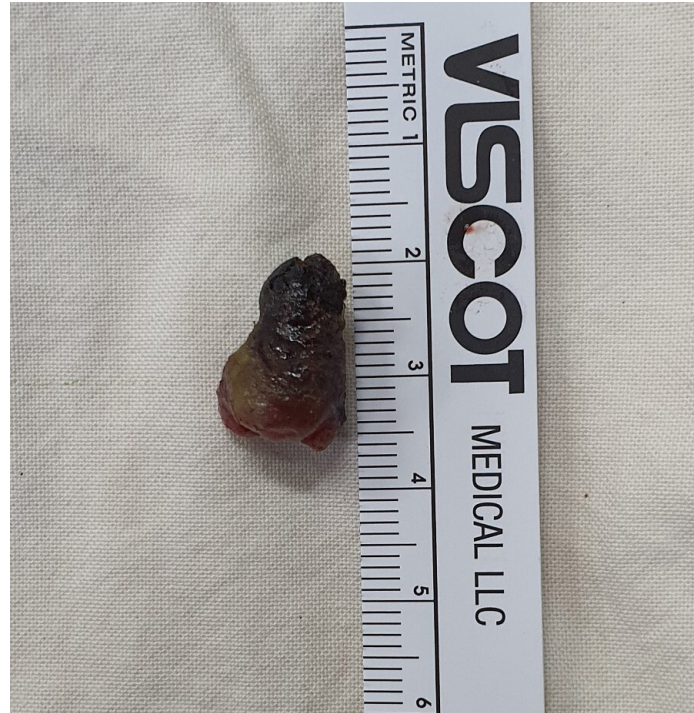

Figure 2 Excised mass measuring $16 \times 12 \mathrm{~mm}$ in size.

are four main types of Aspergillus: Aspergillus fumigatus, A. flavus, A. lentulus and A. nidulans. A. fumigates and $A$. flavus are the most common fungal contaminants of the sinuses and have the potential to infect the orbit. ${ }^{3}$ Invasive sino-orbital aspergillosis in healthy individuals have often been reported from South Asian countries as India. These regions share a hot and humid climate which favours fungal growth and there are a large number of fungal spores in the environment. Even healthy individuals are at risk of sino-orbital aspergillosis. However, it is more seen in immunocompromised hosts.

A pregnant woman has a predisposition to individual microorganisms, depending on how the immune response of her fetoplacental unit behaves. ${ }^{4}$ It is a distinctive immunological state, making the individual vulnerable to a specific set of infectious diseases and resistant to others. Thereby making it a challenging task to decide on how to strategise,

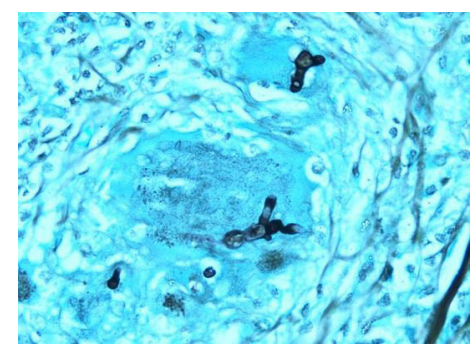

Figure 3 Histopathology slides showing septate hyphae, suggestive of Aspergillus infection. 


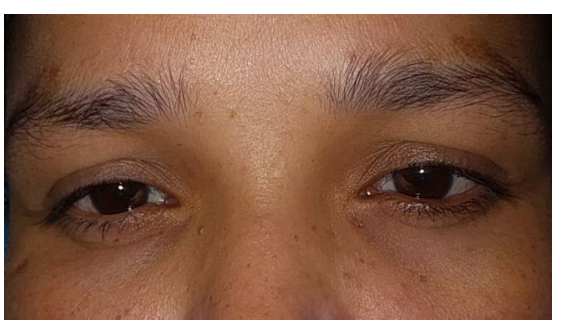

Figure 4 Clinical picture of the patient at 3-week follow-up.

prevent and treat any such infections during pregnancy. As and when required, the maternal immune system sends signals and alerts to keep up the safety and security of both the mother and the fetus, it being a strengthened grid of identification, relay and repair. Therefore, pregnancy cannot be called an immunecompromised situation.

This eccentric behaviour describes the varied response of a pregnant woman to a pathogen. Thus, making pregnancy, not

\section{Patient's perspective}

I had a large mass in my left eyelid, I am happy that the doctors removed it.

\section{Learning points}

Aspergillus infection can occur in immunocompetent pregnant individuals and presentations may be varied.

- Prompt treatment can have favourable results. just an immunocompromised state, but rather a condition with modulation of the immune system responding to the microorganism or its products differently in its various stages.

In this case, a slow-growing mass was assumed to be a pyogenic granuloma given the hormonal status in pregnancy. The immunomodulation could be one of the reasons that there was minimal reaction to a florid fungal proliferation. Treatment in this case was preferred to be topical (given the limited experience with antifungal drugs in pregnancy) but oral drugs could be used in case of a severe infection after the first trimester so that the potential teratogenic effect can be minimised.

Contributors DD and SM were the primary point of contact of patient and the operating surgeon. They also helped in critical revision of the article. AB helped in collecting data, images of patient and histopathology. SA drafted the article.

Funding The authors have not declared a specific grant for this research from any funding agency in the public, commercial or not-for-profit sectors.

Competing interests None declared.

Patient consent for publication Obtained.

Provenance and peer review Not commissioned; externally peer-reviewed.

\section{ORCID iDs}

Deepsekhar Das http://orcid.org/0000-0002-4446-0274

Sujeeth Modaboyina http://orcid.org/0000-0002-1306-5722

Sahil Agrawal http://orcid.org/0000-0001-6667-249X

\section{REFERENCES}

1 Shivaji S, Jayasudha R, Sai Prashanthi G, et al. The human ocular surface fungal microbiome. Invest Ophthalmol Vis Sci 2019;60:451-9.

2 Acharya I, Basa D, Kavitha M. First case report of isolated Aspergillus Dacryoadenitis. Indian J Ophthalmol 2016;64:462-4.

3 Boes B, Bashir R, Boes C, et al. Central nervous system aspergillosis. Analysis of 26 patients. J Neuroimaging 1994:4:123-9.

4 Mor G, Cardenas I. The immune system in pregnancy: a unique complexity. Am J Reprod Immunol 2010;63:425-33.

Copyright 2020 BMJ Publishing Group. All rights reserved. For permission to reuse any of this content visit

https://www.bmj.com/company/products-services/rights-and-licensing/permissions/

BMJ Case Report Fellows may re-use this article for personal use and teaching without any further permission.

Become a Fellow of BMJ Case Reports today and you can:

- Submit as many cases as you like

- Enjoy fast sympathetic peer review and rapid publication of accepted articles

- Access all the published articles

- Re-use any of the published material for personal use and teaching without further permission

Customer Service

If you have any further queries about your subscription, please contact our customer services team on +44 (0) 2071111105 or via email at support@bmj.com.

Visit casereports.bmj.com for more articles like this and to become a Fellow 